\title{
PENGARUH EKSTRAK PROPOLIS TERHADAP PENINGKATAN EKSPRESI p21, EKSPRESI PROTEIN Bax DAN INDUKSI APOPTOSIS PADA KULTUR SEL KANKER KOLON (CELL LINE WiDr)
}

\author{
THE EFFECT OF PROPOLIS EXTRACT ON THE IMPROVEMENT OF EXPRESSION \\ OF p21, Bax PROTEIN EXPRESSION AND INDUCED APOPTOSIS IN CULTURE \\ CANCER CELLS KOLON (CELL LINE WiDr)
}

\author{
Didik Prasetyo, Suradi Maryono, Bambang Purwanto \\ Sub Bagian Hemato Onkologi Medik, Bagian Ilmu Penyakit Dalam \\ FK UNS / RSUD Dr. Moewardi Surakarta \\ Korespondensi: Didik Prasetyo: prasetyobama@gmail.com
}

\begin{abstract}
ABSTRAK
Kanker kolorektal merupakan kanker ketiga terbanyak dengan lebih dari 1 juta kasus setiap tahunnya dan salah satu kanker dengan mortalitas tertinggi di seluruh dunia. Radioterapi dan kemoterapi pada kanker relatif terbatas karena toksisitasnya yang tinggi dan efek samping yang bersifat merusak. Pengembangan propolis merupakan strategi baru untuk terapi adjuvan yang diharapkan meminimalkan efek samping terapi standar yang ada. Peran propolis pada keganasan terkait kemampuannya dalam menginduksi apoptosis dan aktivitas antiproliferasi. Penelitian in vitro, menunjukkan propolis memiliki aktivitas proapoptosis pada berbagai jenis sel kanker, meliputi : kanker laring, kanker paru, kanker pankreas, kanker tiroid, kanker payudara, kanker prostat dan glioma. Penelitian ini bertujuan untuk mengetahui pengaruh pemberian propolis yang berasal dari Kerjo, Karanganyar, Indonesia terhadap aktivitas antiproliferasi, terkait peningkatan ekspresi p21 dan induksi apoptosis terkait peningkatan ekspresi protein bax pada kultur sel kanker kolon (cell line WiDr). Jenis penelitian ini, eksperimental laboratorik dengan post test with control group design. Penelitian menggunakan kultur sel WiDr (sel kanker kolon) dengan pemberian ekstrak etanol propolis (EEP). Pengamatan ekspresi p21 dan protein Bax dengan metode imunositokimia, sedangkan pengamatan induksi apoptosis dengan flowcytometry. Analisis statistik menggunakan uji Kruskall Wallis dilanjutkan Mann WhutneyU test. EEP cenderung menekan viabilitas sel WiDr dengan $I_{50}$ sebesar $140 \mu \mathrm{g} / \mathrm{mL}$. EEP konsentrasi 70,140, $280 \mu \mathrm{g} / \mathrm{mL}$ mampu meningkatkan ekspresi p21 yang sebanding dengan peningkatan konsentrasi yang diberikan. EEP konsentrasi $70 \mu \mathrm{g} / \mathrm{mL}\left(1 / 2 \mathrm{IC}{ }_{50}\right)$ paling efektif dalam menginduksi apoptosis dan meningkatkan ekspresi Bax pada sel WiDr. Peningkatan konsentrasi EEP mengakibatkan kematian sel WiDr ke arah nekrosis. Penelitian ini menunjukkan EEP mampu menekan viabilitas sel WiDr. Aktivitas ini kemungkinan terkait dengan kemampuannya dalam meningkatkan ekspresi p21 sebanding dengan peningkatan konsentrasi yang diberikan. EEP pada konsentrasi $70 \mu \mathrm{g} / \mathrm{mL}$ mampu menginduksi apoptosis pada sel WiDr terkait dengan peningkatan ekspresi Bax. Peningkatan konsentrasi EEP konsentrasi 140 dan 280 $\mu \mathrm{g} / \mathrm{Ml}$ mengakibatkan nekrosis sel WiDr.
\end{abstract}

Kata kunci: EEP, p21, protein bax, cell line WiDr

\begin{abstract}
Colorectal cancer is the third most cancers with more than 1 million cases each year and one of the cancers with the highest mortality worldwide. Radiotherapy and chemotherapy in cancer is relatively limited because of its high toxicity and side effects of a destructive nature. Propolis is a new development strategy for adjuvant therapy which is expected to minimize the side effects of standard therapy available. The role of propolis in malignancy related to its ability to induce apoptosis and anti-proliferation activities. In vitro studies showed propolis has proapoptosis activity on various types of cancer cells, including: laryngeal cancer, lung cancer, pancreatic cancer, thyroid cancer, breast cancer, prostate cancer and glioma. This study is aimed to determine the effect of propolis originating from Kerjo, Karanganyar, Indonesia against anti-proliferation activities, related to increased expression of 21 and induction of apoptosis related to the increased expression of Bax protein in cultured colon cancer cells (cell line WiDr). This study is a laboratory experimental with post test with control group design. Research using
\end{abstract}


cell culture WiDr (colon cancer cells) with ethanol extract of propolis (EEP). Observations expression of 21 and Bax protein by immunocytochemistry method, whereas the induction of apoptosis by flowcytometry observations. Statistical analysis using Kruskal Wallis test followed Mann WhitneyU test. EEP tend to suppress WiDr cell viability with IC50 of $140 \mathrm{mg} / \mathrm{mL}$. EEP concentration of 70.140, $280 \mathrm{mg} / \mathrm{mL}$ can improve p21 expression that is comparable to the increasement in concentration given. EEP concentration of $70 \mathrm{ug} / \mathrm{mL}(1 / 2$ IC50) is most effective in inducing apoptosis and increasing the expression of Bax in WiDr cells. Increasing concentrations of EEP can cause WiDr cell death toward necrosis. This study shows EEP able to suppress WiDr cell viability. This activity is probably related to its ability to improve p21 expression is proportional to the increasement in concentration given. EEP concentration of $70 \mu \mathrm{g} / \mathrm{mL}$ was able to induce apoptosis in cells WiDr associated with increased expression of Bax. EEP concentrations of 140 and $280 \mathrm{mg} / \mathrm{mL}$ cause WiDr cell necrosis.

Keywords: EEP, p21, Bax protein, cell line WiDr.

\section{PENDAHULUAN}

Kanker merupakan penyebab kematian utama, baik di negara maju maupun negara berkembang. Berdasarkan Globocan, pada tahun 2012 di seluruh dunia terdapat sekitar 14,1 juta kasus baru dan 8,2 juta kematian akibat kanker (Torre et al., 2015). Di Indonesia, kanker menempati urutan kelima sebagai penyebab kematian dan angka kematian akibat kanker meningkat dari tahun ke tahun. Pada tahun 1992, angka kematian akibat kanker sebesar 4,8\%, meningkat menjadi $5 \%$ pada tahun 1995 , dan semakin meningkat menjadi $6 \%$ pada tahun 2001 sehingga kanker menjadi masalah kesehatan di masyarakat dengan prevalensi 4,3 per 1000 penduduk (SKRT, 2002; Depkes RI, 2009).

Kanker kolorektal merupakan kanker ketiga terbanyak di seluruh dunia, dengan lebih dari 1 juta kasus setiap tahunnya. Kanker ini mengakibatkan 0,7 juta kematian pada tahun 2012 dan merupakan salah satu kanker dengan angka kematian tertinggi di seluruh dunia (Globocan., 2013 ; Siegel et al., 2014). Di Indonesia, kanker kolorektal merupakan jenis keganasan saluran cerna yang menempati urutan kedua terbanyak setelah kanker hepatoseluler. Berdasarkan data dari Indonesian Cancer, pada tahun2002 ditemukan sebanyak 3.572 kasus baru kanker kolorektal di Indonesia (Kurniawati dan Tenggara., 2011).

Mortalitas yang tinggi pada pasien kanker kolorektal dipengaruhi oleh kemampuan kanker tersebut metastasis ke organ yang jauh (Ottaiano et al., 2006). Sekitar 20\% dari kasus kanker kolorektal yang telah metastasis ini pada umumnya inoperable dan relatif tidak dapat disembuhkan dengan 5-year survival rate sebesar 12\% (Wang dan Zhang., 2014). Aplikasi terapi dengan menggunakan radioterapi dan kemoterapi relatif terbatas karena toksisitasnya yang tinggi dan efek samping yang bersifat merusak. Pendekatan yang menarik untuk dikembangkan adalah penggunaan kombinasi kemoterapi atau sering disebut sebagai ko-kemoterapi. Ko-kemoterapi merupakan strategi terapi kanker dengan mengkombinasikan suatu senyawa kemopreventif yang bersifat tidak toksik dengan agen kemoterapi. Hal ini dapat meningkatkan efikasi agen kemoterapi karena adanya kombinasi yang sinergis dan memperkecil kemungkinan efek samping karena mengurangi dosis agen kemoterapi (Alison, 2004). Aplikasi ko-kemoterapi ini diharapkan dapat menurunkan toksisitas terhadap jaringan normal. Oleh karena itu, pengembangan terapi alternatif merupakan strategi yang mungkin dapat menurunkan efek samping dari terapi kanker kolorektal (Naithani et al., 2008).

Salah satu bahan alam yang potensial dikembangkan sebagai agen ko-kemoterapi adalah propolis. Propolis merupakan suplemen nutrisi yang dihasilkan oleh lebah dan telah digunakan sebagai pengobatan tradisional di dunia. Selain itu, propolis juga telah digunakan secara aman oleh dokter di Brazil, Jepang dan beberapa negara lain sebagai nutrisi suportif yang menyertai terapi standar untuk kanker (Paulino et al., 2009). Propolis terdiri dari campuran resin, serbuk sari dan lilin tanaman yang dikumpulkan lebah dari berbagai jenis tanaman dan digunakan untuk proteksi sarang lebah dari mikroba (Ananda et al., 2013 ; Watanabe et al., 2011).

Propolis mengandung berbagai senyawa kimiawi, seperti polyphenol (flavanoids, asam fenolat dan esternya, aldehid fenolat, alkohol dan keton), terpenoid, steroid, asam amino dan berbagai komponen in organik (Kartal et al. 2003). Komposisi senyawa kimiawi dan aktivitas biologi propolis bervariasi tergantung lokasi geografi, asal tanaman, musim dan spesies lebah (Paulino et 
al., 2009). Propolis telah dibuktikan mempunyai berbagai aktivitas biologis seperti antibakteri, antijamur, antivirus, anestetik lokal, antiinflamasi, antioksidan,hepatoprotektor, imunostimulator, antikanker (antiproliferatif dan proapoptosis) serta berperan pada proses penyembuhan luka (Paulino et al., 2009 ; Vatansever et al., 2010 ; Kubina et al., 2015).

Hal yang relatif menjanjikan dari propolis, yaitu terkait dengan aktivitas antikanker yang dimilikinya. Sejak tahun 2003, berbagai penelitian memfokuskan pada pengaruh propolis terhadap sinyal tranduksi intraseluler yang menunjukkan bahwa beberapa target penting pada sel kanker dapat dimodulasi melalui pemberian propolis. Propolis mempengaruhi protein proapoptosis (Bax, Bak, caspase 3, cytochrome C), protein regulator diferensiasi sel (p38, p56, p21, cyclin dependent kinase) dan target yang berperan pada inflamasi yang terkait dengan kanker, seperti $N F \kappa B$ maupun cyclooxigenase two (Paulino et al., 2009).

Pada berbagai penelitian in vitro, propolis menunjukkan aktivitas proapoptosis pada berbagai jenis sel kanker, meliputi : kanker laring, kanker paru, kanker pankreas, kanker tiroid, kanker kolorektal, kanker payudara, kanker prostat dan glioma (Kubina et al., 2015). Aktivitas antikanker propolis ini dipengaruhi oleh geografis dan tumbuhan sebagai asal pengumpulan resin oleh lebah untuk membentuk propolis. Dua faktor tersebut mempengaruhi komposisi dari propolis (Syamsudin et al., 2009).

Berdasarkan fakta-fakta yang diuraikan di atas, mendorong peneliti untuk mengetahui pengaruh pemberian propolis yang berasal dari Kerjo, Karanganyar, Indonesia terhadap peningkatan ekspresi p21 dan induksi apoptosis, terutama terkait dengan peningkatan ekspresi protein Bax pada kultur sel WiDr (cell line kanker kolon). Penelitian ini sebagai upaya penemuan dan pengembangan strategi baru dalam melawan kanker, khususnya kanker kolon dengan memanfaatkan kekayaan sumber daya hayati lokal.

\section{METODE PENELITIAN}

Penelitian ini merupakan penelitian eksperimental laboratorik dengan menggunakan post test with control group design. Penelitian dilakukan pada kultur sel WiDr (sel kanker kolon) dengan pemberian propolis.

Pengamatan ekspresi p21 dan ekspresi protein Bax dilakukan dengan metode imunositokimia, sedangkan pengamatan induksi apoptosis dilakukan dengan flowcytometry menggunakan pewarnaan annexin $V$ dan propidium iodida (PI).

\section{HASIL DAN PEMBAHASAN \\ 1. Uji sitotoksisitas dengan MTTassay untuk menetapkan nilai $\mathrm{IC}_{50}$ ekstrak etanol propolis dan 5-Fluorouracil.}

Sel WiDr ditumbuhkan pada media komplit, selanjutnya diberikan perlakuan dengan ekstrak etanol propolis. Sel $\mathrm{WiDr}$ yang hidup memiliki morfologi berbentuk poligonal dan menempel pada dasar sumuran, sedangkan sel WiDr yang mati bentuknya menjadi bulat dan lebih kecil dari sel hidup, tersebar dan tidak menempel pada dasar sumuran. Morfologi sel WiDr ditunjukkan pada Gambar 1.

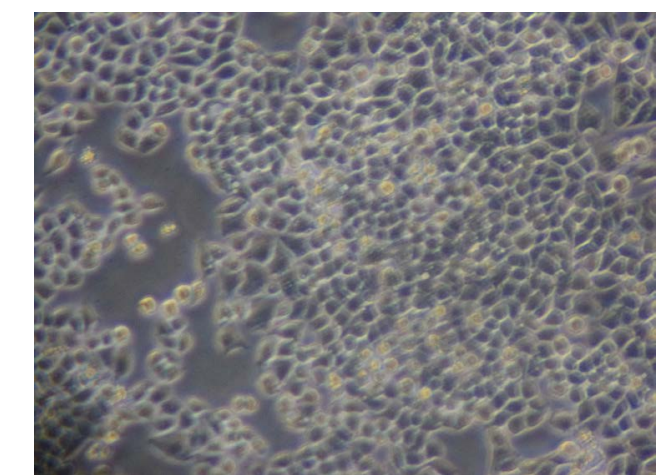

Gambar 1. Morfologi Sel WiDr, sel hidup ditunjukkan panah warna hijau dan sel mati ditunjukkan panah warna merah. Sel diamati dengan mikroskop inverted dengan perbesaran 100 kali

Data yang didapatkan dari uji sitotoksisitas dengan MTT assay berupa absorbansi dari tiap sumuran yang merupakan hasil pembacaan dengan ELISA reader pada panjang gelombang $595 \mathrm{~nm}$. Untuk mendapatkan persentase viabilitas sel, data tersebut kemudian diolah lebih lanjut dengan cara membandingkan nilai absorbansi antara sel yang diberi perlakuan dan kontrol (sel tanpa perlakuan) setelah masing-masing dikurangi dengan kontrol media (blank). Data tersebut digunakan untuk menetapkan nilai $\mathrm{IC}_{50}$ bahan uji dengan menggunakan analisis regresi linear antara 
dosis bahan uji dan persentase viabilitas sel WiDr. Nilai rata-rata persentase viabilitas sel $\mathrm{WiDr}$ dan $\mathrm{IC}_{50}$ dari bahan uji ditunjukkan pada Tabel 1
Tabel 1. Nilai rata-rata persentase viabilitas sel $W i D r$ dan nilai $\mathrm{IC}_{50}$ bahan uji dengan metode MTT assay.

\begin{tabular}{|c|c|c|c|}
\hline Bahan Uji & $\begin{array}{c}\text { Konsentrasi } \\
(\mu \mathrm{g} / \mathrm{mL})\end{array}$ & $\begin{array}{c}\text { Rata-rata viabilitas } \\
\text { sel } \operatorname{WiDr}(\% \pm \mathrm{SD})\end{array}$ & $\begin{array}{c}\mathrm{IC}_{50} \pm \mathrm{SD}(\mu \mathrm{g} / \\
\mathrm{mL})\end{array}$ \\
\hline \multirow{5}{*}{$\begin{array}{l}\text { Ekstrak Etanol } \\
\text { Propolis (EEP) }\end{array}$} & 12,5 & $126,60 \pm 7,92$ & \multirow{5}{*}{$139,61 \pm 49,48$} \\
\hline & 25 & $103,93 \pm 7,23$ & \\
\hline & 50 & $67,78 \pm 1,63$ & \\
\hline & 100 & $34,48 \pm 2,10$ & \\
\hline & 200 & $15,31 \pm 1,75$ & \\
\hline \multirow{5}{*}{$\begin{array}{l}\text { 5-Fluorouracil } \\
\quad(5-\mathrm{FU})\end{array}$} & 12,5 & $118,57 \pm 5,57$ & \multirow{5}{*}{$502,33 \pm 60,52$} \\
\hline & 25 & $114,17 \pm 3,83$ & \\
\hline & 50 & $112,61 \pm 6,86$ & \\
\hline & 100 & $105,37 \pm 3,09$ & \\
\hline & 200 & $91,27 \pm 4,86$ & \\
\hline
\end{tabular}

Tabel 1. Menunjukkan bahwa secara umum peningkatan konsentrasi EEP mengakibatkan penurunan persentase viabilitas sel $W i D r$. Pada konsentrasi EEP yang tertinggi $(200 \mu \mathrm{g} / \mathrm{mL})$, diperoleh persentase viabilitas sel $\mathrm{WiDr}$ yang terendah $(15,31 \%)$. Pada pemberian 5-FU secara umum tidak seefektif pemberian EEP, karena pada konsentrasi yang tertinggi $(200 \mu \mathrm{g} / \mathrm{uL})$ persentase viabilitas sel WiDr masih mencapai 91,27\%.

Dari analisis regresi linear diperoleh $\mathrm{IC}_{50}$ EEP sebesar 139,61 $\mu \mathrm{g} / \mathrm{mL}$. Nilai IC $_{50}$ EEP ini digunakan sebagai dasar penentuan konsentrasi EEP yang digunakan pada penelitian selanjutnya, yaitu sebesar 70, 140, dan $280 \mu \mathrm{g} / \mathrm{mL}\left(1 / 2 \mathrm{IC}_{50} \mathrm{IC}_{50}\right.$, dan $2 \mathrm{IC}_{50}$ ). Nilai $\mathrm{IC}_{50}$ 5-FU yaitu sebesar 502,33 $\mu \mathrm{g} / \mathrm{mL}$ akan digunakan sebagai pembanding (kontrol positif).

\section{Pengamatan ekspresi p21}

P21 adalah protein yang memiliki fungsi utama dalam regulasi progresivitas siklus sel dengan menghalangi ikatan antara CDK dan cyclin (Abukahader \& Park, 2005). Untuk mengetahui apakah penghambatan proliferasi sel $\mathrm{WiDr}$ setelah pemberian EEP selama 24 jam terkait peningkatan ekspresi p21, maka dilakukan pengamatan ekspresi p21 pada sel WiDr dengan pengecatan imunositokimia. Pengecatan imunositokimia untuk ekspresi p21 dilakukan pada 5 kelompok perlakuan (kontrol, EEP $1 / 2$ IC50, EEP IC50, EEP 2IC50 dan 5FU IC50) dan masing-masing kelompok perlakuan tersebut dibuat triplicate.

Data yang diperoleh berupa persentase sel yang mengekspresikan p21 (tampak sebagai warna coklat pada inti sel maupun sitoplasma) dari keseluruhan sel pada 5 lapangan pandang (Gambar 2). Penilaiannya dilakukan pada 3 slide dari tiap-tiap kelompok perlakuan. 

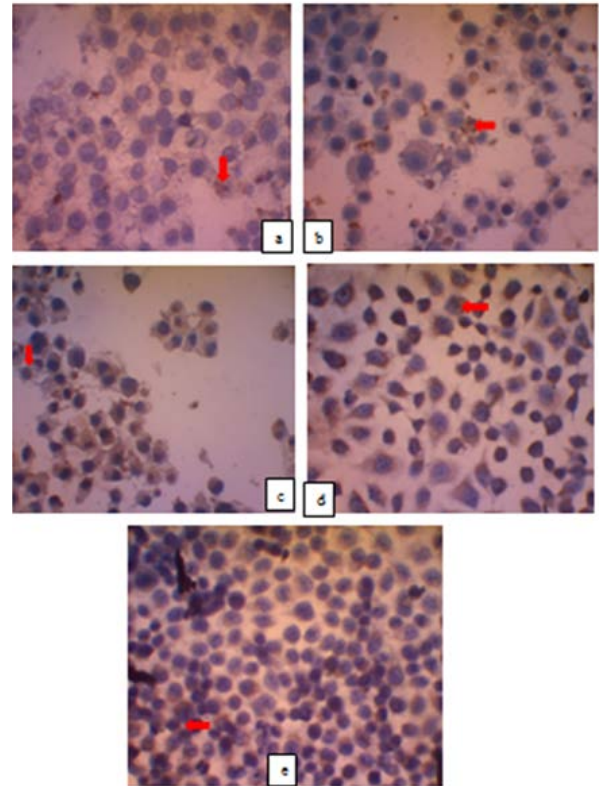

Gambar 2. Hasil pengecatan imunositokimia perbesaran 400 kali untuk ekspresi p21 pada sel WiDr setelah perlakuan dan inkubasi selama 24 jam pada kelompok dengan EEP konsentrasi $\frac{1}{2} \mathrm{IC} 50$ (a), $\mathrm{IC}_{50}$ (b), 2IC $\mathrm{IC}_{50}$ (c), kelompok dengan 5-FU (d) dan kelompok kontrol (e). Sel yang mengekspresikan p21 ditunjukkan dengan panah warna merah.

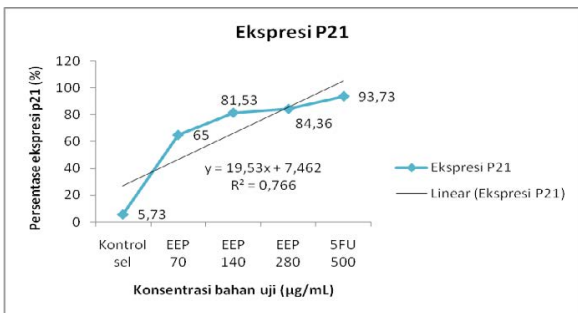

Gambar 3. Hubungan antara konsentrasi bahan uji dengan rata-rata persentase ekspresi p21 pada sel $\mathrm{WiDr}$ setelah inkubasi 24 jam.

Dari grafik di atas, terlihat bahwa pemberian EEP selama 24 jam meningkatkan ekspresi p21. Peningkatan ekspresi p21 sebanding dengan peningkatan konsentrasi EEP yang diberikan.

Hasil uji statistik menunjukkan adanya perbedaan ekspresi p21 yang bermakna diantara semua kelompok perlakuan yang mendapatkan EEP konsentrasi 70, 140 dan $280 \mu \mathrm{g} / \mathrm{mL}$ dibandingkan dengan kelompok kontrol positif (5FU) maupun kelompok kontrol tanpa perlakuan.

\section{Uji induksi apoptosis EEP pada sel WiDr dengan flowcytometry}

Uji induksi apoptosis dilakukan untuk mengetahui kemampuan EEP dalam menginduksi apoptosis sel WiDr. Uji ini dilakukan pada lima kelompok perlakuan, yaitu kelompok dengan EEP konsentrasi 70, 140,280 $\mu \mathrm{g} / \mathrm{mL}\left(1 / 2 \quad \mathrm{IC}_{50}, \mathrm{IC}_{50}\right.$ dan $2 \mathrm{IC}_{50}$ ), kelompok dengan 5-FU konsentrasi $500 \mu \mathrm{g} / \mathrm{mL}\left(\mathrm{IC}_{50}\right)$, dan kelompok kontrol tanpa perlakuan. Morfologi sel $\mathrm{WiDr}$ pada kelima kelompok perlakuan setelah inkubasi selama 24 jam ditunjukkan pada Gambar 4.
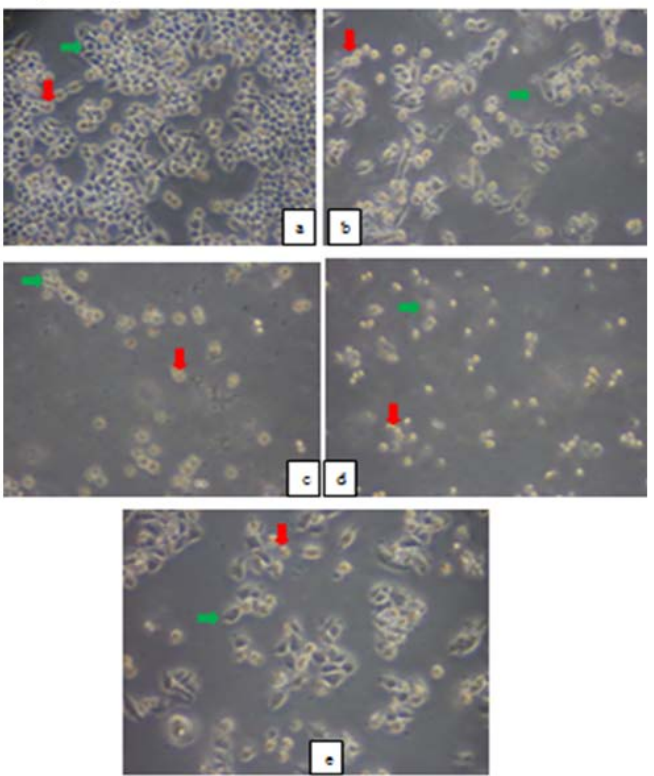

Gambar 4. Gambar sel WiDr dengan perbesaran 100 kali, untuk uji apoptosis setelah inkubasi 24 jam pada kelompok kontrol (a), kelompok dengan pemberian EEP konsentrasi

$70 \mu \mathrm{g} / \mathrm{mL}$ (b), $140 \mu \mathrm{g} / \mathrm{mL}$ (c), $280 \mu \mathrm{g} / \mathrm{mL}$ (d), serta kelompok dengan pemberian 5-FU $500 \mu \mathrm{g} / \mathrm{mL}$ (e). Sel hidup ditunjukkan dengan panah warna hijau,sedangkan sel mati dengan panah warna merah.

Setelah inkubasi selama 24 jam, dilakukan uji apoptosis dengan metode flowcytometry dan tiap-tiap kelompok perlakuan dibuat duplo. Data hasil flowcytometry yang diperoleh berupa persentase sel WiDr yang hidup, mengalami apoptosis, maupun nekrosis pada kelima kelompok perlakuan (Gambar 5). 


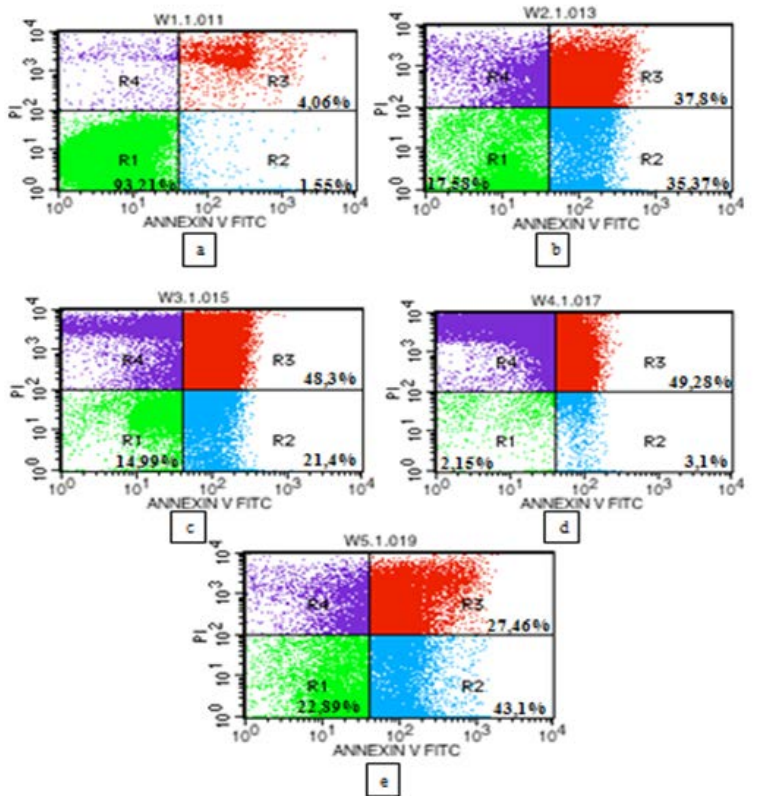

Gambar 5. Hasil flowcytometry sel WiDr setelah perlakuan dan inkubasi selama 24 jam pada kelompok kontrol (a), kelompok dengan pemberian EEP konsentrasi $1 \frac{1}{2} \mathrm{IC}_{50}(\mathrm{~b})$, $\mathrm{IC}_{50}(\mathrm{c})$ dan $2 \mathrm{IC}_{50}(\mathrm{~d})$ serta kelompok dengan pemberian 5-FU konsentrasi $\mathrm{IC}_{50}(\mathrm{e})$

Keterangan untuk tiap-tiap kuadran :

a. Kiri Bawah (Anexin negatif, PI negatif): Sel Hidup

b. Kanan Bawah (Anexin positif, PI negatif): Sel Apotosis

c. Kanan Atas (Anexin positif, PI positif): Sel Nekrosis

Tabel 2. Rata-rata persentase sel WiDr yang mengalami apoptosis setelah inkubasi selama 24 jam dengan bahan uji (EEP dan 5-FU) maupun pada kelompok kontrol.

\begin{tabular}{lcc}
\hline Perlakuan & $\begin{array}{c}\text { Konsentrasi } \\
(\boldsymbol{\mu g} / \mathbf{m L})\end{array}$ & $\begin{array}{c}\text { Rata-rata Apoptosis } \\
\text { Sel } \boldsymbol{W i D r}(\%) \pm \mathbf{S D}\end{array}$ \\
\hline Kontrol Sel & 0 & $1,55 \pm 0,05$ \\
EEP & $70 \quad\left(1 / 2 \mathrm{IC}_{50}\right)$ & $35,37 \pm 1,2$ \\
& $140\left(\mathrm{IC}_{50}\right)$ & $21,88 \pm 0,67$ \\
5 5-FU & $280\left(2 \mathrm{IC}_{50}\right)$ & $3,11 \pm 0,13$ \\
\hline
\end{tabular}

Data pada tabel 2 menunjukkan bahwa rata-rata persentase apoptosis pada sel WiDr yang diberikan EEP lebih kecil dibandingkan dengan kelompok kontrol positif yang diberikan 5-FU. EEP pada konsentrasi $1 / 2 \mathrm{IC}_{50}$ mampu menginduksi apoptosis sel $\mathrm{WiDr}$ yang paling tinggi dibandingkan dengan konsentrasi EEP yang lain $\left(\mathrm{IC}_{50}\right.$ dan $\left.2 \mathrm{IC}_{50}\right)$. Hal ini menunjukkan bahwa semakin besar konsentrasi EEP yang diberikan akan menginduksi terjadinya nekrosis pada sel WiDr.

Hasil statistik menunjukkan terdapat perbedaan rata-rata persentase apoptosis sel WiDr yang bermakna secara statistik pada semua kelompok. Perbedaan yang tidak bermakna secara statistik terdapat diantara kelompok kontrol sel dengan kelompok perlakuan yang mendapatkan EEP konsentrasi $280 \mu \mathrm{g} / \mathrm{mL}\left(2 \mathrm{IC}_{50}\right)$

\section{Pengamatan ekspresi protein bax}

Protein bax adalah protein yang diidentifikasi sebagai protein proapoptosis. Peningkatan protein ini mengakibatkan sel lebih sensitif terhadap apoptosis (Dash, 2003). Oleh karena itu, untuk mengetahui apakah peningkatan apoptosis sel $W i D r$ setelah pemberian EEP selama 24 jam terkait peningkatan ekspresi protein bax, maka dilakukan pengamatan peningkatan ekspresi protein bax pada sel $W i D r$ dengan pengecatan imunositokimia. Pengecatan imunositokimia dilakukan pada 5 kelompok (kontrol, 1/2 IC50, IC50, 2IC50 dan 5FU) dan masing-masing kelompok tersebut dibuat triplicate.

Data yang diperoleh berupa persentase sel yang mengekspresikan protein bax (tampak sebagai warna coklat pada inti sel maupun sitoplasma) dari keseluruhan sel pada 5 lapangan pandang dan penilaiannya dilakukan pada 3 slide dari tiap-tiap kelompok perlakuan (Gambar 6) . 

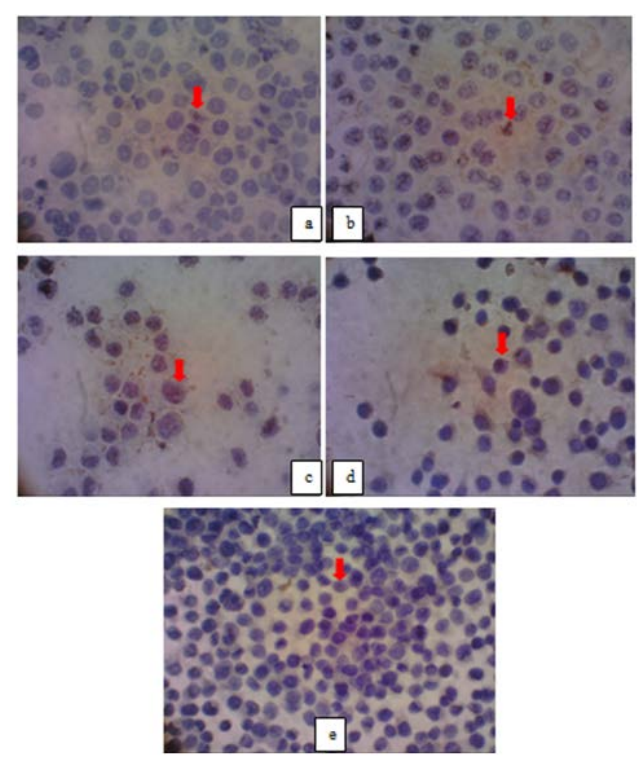

Gambar 6. Hasil pengecatan imunositokimia perbesaran 400 kali untuk ekspresi protein bax pada sel WiDr setelah perlakuan dan inkubasi selama 24 jam pada kelompok dengan EEP konsentrasi $1 / 2$ IC50 (a), $\mathrm{IC}_{50}$ (b), 2IC $\mathrm{IC}_{50}$ (c), 5-FU (d) dan kontrol (e). Sel yang mengekspresikan protein bax ditunjukkan dengan panah warna merah.

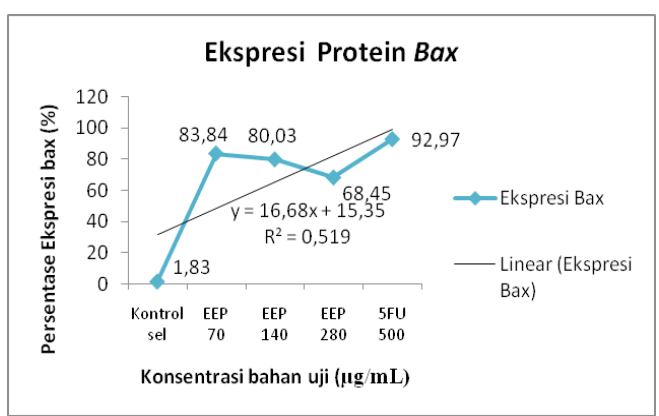

Gambar 7. Hubungan antara konsentrasi bahan uji dengan rata-rata persentase ekspresi protein bax pada sel $\mathrm{WiDr}$ setelah inkubasi 24 jam.

Dari grafik di atas, terlihat bahwa pemberian EEP selama 24 jam meningkatkan ekspresi protein bax. Peningkatan ekspresi protein bax yang paling tinggi terdapat pada kelompok dengan pemberian EEP konsentrasi $70\left(1 / 2 \mathrm{IC}_{50}\right)$. Hasil uji statistik menunjukkan adanya perbedaan ekspresi protein bax yang bermakna diantara semua kelompok perlakuan yang mendapatkan EEP konsentrasi 70, 140 dan $280 \mu \mathrm{g} / \mathrm{mL}$ dibandingkan dengan kelompok kontrol positif (5-FU) maupun kelompok kontrol tanpa perlakuan.

Penelitianinidiawalidenganujisitotoksisitas senyawa ekstrak etanol propolis (EEP) pada sel
WiDr menggunakan metode MTT assay. Uji sitotoksisitas ini dilakukan untuk menetapkan nilai $\mathrm{IC}_{50}$ senyawa EEP yang selanjutnya akan digunakan sebagai dasar penetapan konsentrasi EEP untuk pengamatan ekspresi p21, protein bax maupun uji induksi apoptosis pada sel WiDr. Selain itu, uji sitotoksisitas ini juga digunakan untuk menetapkan $\mathrm{IC}_{50}$ 5-fluorouracil (5-FU) pada sel $\mathrm{WiDr}$ sebagai kontrol positif pada uji induksi apoptosis.

Pada uji sitotoksisitas ini secara umum didapatkan persentase viabilitas sel $\mathrm{WiDr}$ semakin menurun sebanding dengan peningkatan konsentrasi EEP yang diberikan (Tabel 5). Hal ini menunjukkan bahwa pemberian EEP konsentrasi 70-280 ug/mL selama 24 jam mampu menghambat proliferasi sel $\mathrm{WiDr}$.

Hasil ini sejalan dengan beberapa penelitian eksperimen in vitro yang menyatakan bahwa EEP mampu menghambat pertumbuhan berbagai sel tumor dikarenakan mempunyai efek sitotoksik, antiproliferatif dan induksi apoptosis (Kubina et al, 2015). Szliszka et al. (2012) melaporkan bahwa pemberian EEP dengan konsentrasi 5, 25, $50 \mathrm{ug} / \mathrm{mL}$ selama 48 jam mampu menghambat proliferasi cell line HeLa yang merupakan turunan kanker servik.

Selanjutnya aktivitas sitotoksisitas EEP pada sel $W i D r$ setelah inkubasi 24 jam dinyatakan dengan nilai $\mathrm{IC}_{50}$ yang diperoleh melalui analisis regresi linear. Pada analisis tersebut diperoleh $\mathrm{IC}_{50}$ EEP pada sel WiDr di penelitian ini sebesar 139,32 ug/mL. Szliszka et al. (2011) melaporkan bahwa konsentrasi EEP $50 \mathrm{ug} / \mathrm{mL}$ dari Negara Polandia bagian selatan mempunyai efek sitotoksisitas $25 \%$ pada cell line kanker prostat. Vatansever et al. (2010) menunjukkan bahwa EEP konsentrasi 125 $\mathrm{ug} / \mathrm{mL}$ mempunyai efek sitotoksik pada sel MCF7 (cell line kanker payudara). Vatansever et al. (2010) juga melaporkan bahwa terdapat perbedaan efek sitotoksik dari tujuh sampel EEP yang berbeda yang dikumpulkan dari lokasi yang sama. Penelitian ini mengindikasikan bahwa komposisi kimia dan farmakokinetik EEP berbeda-beda. Hal ini selain dipengaruhi oleh geografis juga dipengaruhi jenis tanaman, asal propolis tersebut diperoleh.

Pada uji sitotoksisitas ini secara umum didapatkan persentase viabilitas sel $\mathrm{WiDr}$ semakin menurun sebanding dengan peningkatan 
konsentrasi EEP yang diberikan (Tabel.1). Hal ini menunjukkan bahwa pemberian EEP pada penelitian ini selama 24 jam mampu menghambat proliferasi dan menurunkan viabilitas sel $\mathrm{WiDr}$. Hal ini sesuai dengan penelitian Ishihara et al.(2009), mengenai efek anti proliferasi dari ekstrak etanol propolis yang berasal dari Cina dan Brazil pada cell line kanker kolorektal.

Motomura et al. (2008) melaporkan bahwa ekstrak methanol propolis konsentrasi 100-1000 $\mu \mathrm{g} / \mathrm{mL}$ mampu menghambat pertumbuhan cell line U-937 (sel kanker leukemia) yang sebanding dengan peningkatan konsentrasi yang diberikan. Lie et al. (2007) menunjukkan bahwa propolis dari Mexico mampu menghambat proliferasi sel epitelial paru cell line A-549 manusia dengan $\mathrm{IC}_{50}$ $6,2 \mu \mathrm{M}$ (lebih rendah dari $\mathrm{IC}_{50} 5-\mathrm{FU}$ ).

Hambatan proliferasi sel $\mathrm{WiDr}$ oleh EEP pada penelitian ini kemungkinan terkait dengan kemampuan EEP dalam meningkatkan ekpresi p21 pada sel WiDr. P21 adalah suatu tumor suppresor protein dengan berat $21 \mathrm{KDa}$ memiliki fungsi utama dalam regulasi terhadap progresi siklus sel. Hasil ini terutama dicapai dengan menghalangi ikatan CDK dengan cyclin. Lie et al. (2007) melaporkan hal yang sama, bahwa ekstrak etanol propolis yang berasal dari brasil memiliki efek antiproliferatif melalui peningkatan ekspresi p21 pada sel kanker prostat.

Selain memiliki efek antiproliferasi, pada penelitian ini juga ditunjukkan bahwa propolis dengan konsentrasi $1 / 2 \mathrm{IC}_{50}(70 \mu \mathrm{g} / \mathrm{mL})$ mampu menginduksi apoptosis sel $W i D r$ sebesar $35,37 \%$. Beberapa penelitian sebelumnya mendukung hasil tersebut. Syamsudin et al. (2010) melaporkan ekstrak ethyl acetate propolis pada konsentrasi $47,45 \mu \mathrm{g} / \mathrm{mL}$ mengakibatkan peningkatan apoptosis pada cell line MCF-7 yang merupakan turunan kanker payudara sebesar 13,21\%. Pengamatan yang menarik juga dilakukan oleh Lee et al. (2003) yang melaporkan bahwa phenylethyl ester of caffeic acid (CAPE) salah satu komponen dari propolis berpengaruh terhadap aktivitas protein p53 dan protein p38 pada sel glioblastoma. Penelitian tersebut menunjukkan propolis memiliki aktivitas sitotoksik dan induksi pengeluaran cytochrome $\mathrm{c}$ dari mitokondria ke sitosol dan mengaktifkan caspase 3. Ekspresi dari protein p53, Bax dan Bak meningkat setelah inkubasi 3 jam dan juga menurunkan ekspresi protein antiapoptosis $\mathrm{Bcl} 2$ setelah inkubasi 36 jam. Mootomura et al. (2008) melaporkan propolis mampu meningkatkan apoptosis cell line U-937 (sel kanker leukemia) melalui aktivasi caspase-3 dan penekanan $\mathrm{Bcl}$-2. Sejalan dengan penelitian di atas, Eom et al. (2010) melaporkan bahwa propolis menginduksi apoptosis melalui pelepasan cytochrome $C$ dari mitokondria ke dalam sitosol dan melalui aktivasi caspase-3 pada cell line $H L$ 60 (sel kanker leukemia).

Namun, pada penelitian ini menunjukkan bahwa dengan peningkatan konsentrasi EEP yang diberikan akan menyebabkan kematian sel ke arah nekrosis. Nekrosis merupakan proses kematian sel patologis yang terjadi secara pasif, katabolik dan umumnya merupakan respon terhadap faktor-faktor toksik eksternal, seperti inflamasi, iskemia maupun toxic injury. Nekrosis ditandai dengan adanya pembengkakan mitokondria, ruptur membran plasma, pemisahan kromatin dan destruksi struktur sel yang semula utuh (Wu et al., 2001). Menurut Kumar et al. (2005), pada proses nekrosis terjadi pelepasan komponen sitoplasma sehingga mencetuskan respon inflamasi.

Mekanisme molekuler terkait induksi apoptosis pada penelitian ini juga diamati melalui ekspresi protein bax. Peningkatan ekspresi protein bax pada penelitian ini didapatkan hasil tertinggi pada konsentrasi EEP $1 / 2 \quad \mathrm{IC}_{50}(70 \mu \mathrm{g} / \mathrm{mL})$ yaitu sebesar 83,84\%. Pada konsentrasi EEP yang semakin meningkat, yaitu konsentrasi $\mathrm{IC}_{50}(140$ $\mu \mathrm{g} / \mathrm{mL})$ dan $2 \mathrm{IC}_{50}(280 \mu \mathrm{g} / \mathrm{mL})$, ekspresi bax mengalami penurunan, yaitu sebesar $80,97 \%$ dan $69,45 \%$. Penurunan ekspresi protein bax pada konsentrasi $\mathrm{IC}_{50}(140 \mu \mathrm{g} / \mathrm{mL})$ dan $2 \mathrm{IC}_{50}(280 \mu \mathrm{g} /$ $\mathrm{mL})$ menunjukkan bahwa, kematian sel WiDr dengan pemberian dua konsentrasi EEP tersebut terjadi secara nekrosis dan nekrosis tidak terkait dengan jalur sinyal apoptosis. Berdasarkan hasil ini, konsentrasi optimal EEP untuk menekan viabilitas sel $\mathrm{WiDr}$ melalui mekanisme induksi apoptosis yang terkait dengan peningkatan ekspresi protein bax yaitu sebesar $70 \mu \mathrm{g} / \mathrm{mL}$.

\section{SIMPULAN}

1. Ada pengaruh pemberian ekstrak propolis terhadap peningkatan ekspresi protein $\mathrm{p} 21$ pada kultur sel WiDr.

2. Ada pengaruh pemberian ekstrak propolis konsentrasi $1 / 2 \quad \mathrm{IC}_{50}(70 \mu \mathrm{g} / \mathrm{mL})$ terhadap 
peningkatan ekspresi protein bax pada kultur sel WiDr.
3. Ada pengaruh pemberian ekstrak propolis terhadap induksi apoptosis pada kultur sel WiDr.

\section{DAFTAR PUSTAKA}

Alison, M.R. 2001. Cancer. In : Encyclopedia of Life Seciences. Nature Publishing Group. London. United Kingdom.

Ananda, S.K., Tragoolpua, K., Chantawannakul, P., Tragoolpua, Y. 2013. Antioxidant and anticancer cell proliferation of propolis extracts from two extraction methods. Asian Pac J Cancer Prev. 14(11): 6991-6995.

Departemen Kesehatan RI (Depkes RI). 2009. Profil Kesehatan Indonesia 2008. Departemen Kesehatan Republik Indonesia. Jakarta.

Eom, H.S., Lee, S.J., Yoon, B.S., Yoo, B.S. 2010. Propolis inhibit the proliferation of human leukemia HL-60 cells by inducing apoptosis through the mitochondrial pathway. Nat Prod Res. 24:375386.

Globocan. 2013. Cancer Fact Sheets for Colorectal Cancer.2013. Available from: URL: http://globocan. iarc.fr/Pages/fact_sheets_cancer.aspx

Ishiara M, Naoi K, Hashita M, Itoh Y, Suzui M. 2009. Growth inhibitory activity of ethanol extracts of Chinese and Brazilian propolis in four human colon carcinoma cell lines. Oncol Rep. 22: 349-354.

Kartal, M.,Yildiz, S.,Kaya, S.,Kurucu, S.,Topcu, G. 2003. Anti-microbial activity of propolis samples from two different regions of Anatolia. J Ethnopharmacol. 86:69-73.

Kurniawati, A dan Tenggara, R. 2011. Pengaruh Asam Asetil Salisilat terhadap Penurunan Prevalensi Kanker Kolorektal. CDK. 186: 38(5): 350-352.

Kubina, R., Dzik, A.K., Dziedzic, A., Bielec, B., Wojtczka, R.D., Buldok, R.J., Wysznynska, M., et al. 2015. The ethanol extract of polish propolis exhibits anti-proliferative and/or pro-apoptotic effect on HCT 116 colon cancer and Me45 malignant melanoma cell in vitro conditions. Adv Clin Exp Med. 24(2): 203-212.

Kumar, V., Cotran, R.S., Collins, T. 2005. Neoplasia In Robins Pathologic Basis of Disease, 7th ed. Philadelphia : W.B. Saunders, p.269-342.

Lee YJ, Kuo HC, Chu CY, Wang CJ, Lin WC, Tseng TH. 2003. Involvement of tumor suppressor protein p53 and p38 MAPK in caffeic acid phenethyl ester-induced apoptosis of C6 glioma cells. Biochem Pharmacol. 66: 2281-2289.

Lie, H., Kapur, A., Yang, J.X., Srivastava, S., McLeod, D.G., Paredes-Guzman, J.F et al. 2007. Antiproliferation of human prostat cancer cell by ethanolic extracts of Brasilian propolis and its botanical origin. Int J Oncol; 31:601-06

Motomura, M., Kwon, K.M., Suh, S.J. 2008. Propolis induces cell cycle arrest and apoptosis in human leukemic U937 cells through Bcl-2/Bax regulation. Environ Toxicol Pharmacol. 26:61-67.

Naithani, R., Huma, L.C., Moriarty, R.M., McCormick, D.L., Mehta, R.G. 2008. Comprehensive review of cancer chemopreventive agentsevaluated in experimental carcinogenesis models and clinical trials.Curr Med Chem. 15: 1044-1071.

Ottaiano, A., Franco, R., Aiello, T.A., Liguori, G., Tatangelo, F., Delrio, P., Nasti, G., et al. 2006. Overexpression of bothCXC chemokine receptor 4 and vascular endothelial growth factorproteins predicts early distant relapse in stage II-III colorectalcancer patients. Clin Cancer Res. 12: 2795-2803.

Paulino, N., Abreu, S.R.L., Machodo, G., Silveira, E. 2009. Scientific evidences to pharmacological anticancer action of Baccharis dracunculifolia Brazilian propolis. Rev Pesq Inov Farm. 1(1): 
15-26.

Siegel, R., Ma, J., Zou, Z., Jemal, A. 2014. Cancer statistics.CACancer J Clin.64: 9-29.

Survei Kesehatan Rumah Tangga (SKRT). 2002. Laporan studi mortalitas 2001:pola penyakit penyebab kematian di Indonesia. Badan Litbang Departemen Kesehatan. Jakarta.

Syamsudin Simanjuntak P, Djamil R, Heffe WL. 2010. Apoptosis of human Breast Cancer Cells induced by Ethylacetate Extracts of Propolis. Am J Biochem Biotechnol. 16: 84-88.

Syamsudin, Wiryowidagdo, S., Simanjuntak, P., Heffen, W.L. 2009. Chemical composition of propolis from different region in java and their cytotoxic activity. AJBB. 5(4): 180-183.

Szliszka E, czuba ZP, Domino M, Mazur B, Zydowicz G, Krol W. 2009. Ethanolic extract of propolis (EEP) enhances the apoptosis-inducing potential of TRAIL in cancer cells. Molecules. 14: 738-754.

Torre, L.A., Bay, F., Siegel, R.L., Ferlay, J., Tieulent, J.L., Jemal, A. 2015. Global Cancer Statistic. Ca Cancer J Clin. 65: 87-108.

Vatansever, H.S., Sorkun, K. Gurhan, S.I.D., Ozdal-Kurt, F., Turkoz, E., Gencay, O., Salih, B. 2010. Propolis from Turkey induces apoptosis through activating caspases in human breast carsinoma cell lines. Acta Histochem. 112: 546-556.

Wang, X dan Zhang, Y. 2014. Targeting mTOR network in colorectal cancer therapy. World J Gastroenterol. 20(15): 4178-4188.

Watanabe, M.A.E., Amarante, M.K., Conti, B.J., Sforcin, J.M. 2011. Cytotoxic constituents of propolis inducing anticancer effect: a review. JPP. 63: 1378-1386.

Wu, M., Ding, H.F., Fisher, D.E. 2001. Apoptosis: Molecular Mechanisms. In : Encyclopedia of Life Seciences. Nature Publishing Group. London. United Kingdom. 